\title{
Extracellular Production of Amylase and Protease by Penicillium Purpurogenum BKS9
}

\author{
Bijay Kumar Sethi ${ }^{1, *}$, Brahmananda Dikshit ${ }^{1}$, Santi Lata Sahoo ${ }^{2}$, Chinmay Pradhan $^{2}$, Sangeeta Sena $^{3}$, \\ Bikash Chandra Behera ${ }^{4}$
}

\author{
${ }^{1}$ Department of Botany, KIIT Science College, Campus-8, KIIT University, Patia, India \\ ${ }^{2}$ Microbiology Research Laboratory, P.G. Department of Botany, Utkal University, India \\ ${ }^{3}$ Department of Biotechnology, MITS School of Biotechnology, Utkal University, India \\ ${ }^{4}$ Department of Biotechnology, North Orissa University, India
}

Copyright $\mathrm{O} 2017$ by authors, all rights reserved. Authors agree that this article remains permanently open access under the terms of the Creative Commons Attribution License 4.0 International License

\begin{abstract}
In the present study, Penicillium purpurogenum BKS9 was used with different agro waste substrates i.e. starch, wheat bran, soya powder, boiled rice, unboiled rice and milk powder for the production of both amylase and protease by liquid static surface fermentation (LSSF). Among the various substrates tested, wheat bran (WB) was found to be the best substrate for maximum $(112.64 \mathrm{U} / \mathrm{ml})$ amylase production whereas soya powder $(121.23 \mathrm{U} / \mathrm{ml})$ for production of protease. Immobilization study also revealed that the highest amylase was observed $(137.6 \mathrm{U} / \mathrm{ml})$ when wheat bran was used as substrate whereas maximum protease production $(130.73 \mathrm{U} / \mathrm{ml})$ with soya seed powder. Maximum biomass production was observed $(4.4 \pm$ $0.2 \mathrm{~g} / 50 \mathrm{ml}$ ) when unboiled rice was taken as a substrate in comparison to other substrate.
\end{abstract}

Keywords Biotechnological Agro Food Waste Utilization, Fungi Immobilization, Natural Substrates, Wastes Fermentation

\section{Introduction}

Exploitation of enzymes as bio-catalyst is becoming the best option which gradually replacing chemical catalysts in many areas of industry especially in textile and detergent industries [1]. Further, microbial enzymes are gaining biotechnological importance for their technical and economical advantages [2]. Among all enzymes the fungal amylase and protease are two most imperative enzymes in contemporary biotechnology as they satisfy the industrial needs and almost replaced the chemical hydrolysis of starch and protease in food processing industries and have utmost significance demand. Therefore they hold approximately $25 \%$ of the total enzyme trading [3]. Amylase and protease as extracellular enzymes have potential applications in a number of biotechnological industrial processes such as in food, beverage, sugar, fermentation, detergent, textiles and paper industry [4]. These enzymes are found in animals (saliva, pancreas), plants (malt), bacteria and molds [5]. Sources of amylase and protease in yeast, bacteria and molds have been reported and their properties have been described [6]. Amylase and protease of fungal origin was found to be more stable than the bacterial enzymes on a commercial scale.

Filamentous fungi exhibit numerous inimitable properties that put together them as exceptional candidates for industrial exploitations. Keeping in view of the credentials, many of them have been used for the production of bulk quantities of extracellular enzymes through fermentations [7]. The filamentous fungi generally used for the production of polymer-degrading enzymes are mostly of Aspergillus and Penicillium [7, 8]. Fungi generally produce $\alpha$-amylase (dextrinzing enzymes), beta-amylase (saccharifying enzymes), proteases and other enzymes to survive on this orb. For that, they can utilize a variety of substrates. Among different types of substrates, the agro-substrates are easily available, cheap carbon sources required for the growth of microorganisms, including filamentous fungi and for the production of enzymes. In this context, unboiled rice, boiled rice, wheat bran and soya powders would be the rich source of both macro- and micronutrients essential for the growth of fungi.

Hence in the present study attempt has been made to produce such industrially important amylase and protease enzyme from different fungal sources using cheap and easily available agro waste like unboiled rice, boiled rice, wheat bran, soya powders etc.

\section{Materials and Methods}

\subsection{Inoculums Development}

Penicillium purpurogenum BKS9 (GenBank accession No. 
KT 222270) was used for all the experiments. After receiving, the fungal culture was maintained as pure cultures on Sabouraud's dextrose agar (SDA) medium for further experiments. The differential streaking procedures was performed according to Dubey and Maheswari [9]. The isolated fungal species were also sub-cultured on SDA slants at regular intervals during the entire study period. Spore suspension $(1 \mathrm{ml})$ having spore concentration of about $1 \times$ $10^{7}$ cells $\mathrm{ml}^{-1}$ from 7 days old culture was used as inoculum in the subsequent experiments [10].

\subsection{Liquid Static Surface Fermentation for Production of Amylase and Protease}

Liquid static surface fermentation (LSSF) was carried out in triplicate in $150 \mathrm{ml}$ Erlenmeyer flasks containing $50 \mathrm{ml}$ of sterilized fermentation medium having individually starch, milk powder (amul), wheat bran, soya powder, unboiled rice and boiled rice as substrate. The fermentation medium containing theese substrate was inoculated with $1.5 \times 10^{7}$ cells $\mathrm{ml}^{-1}$ culture of $P$. purpurogenum BKS9 in triplicate and incubated at $30 \pm 2{ }^{\circ} \mathrm{C}$ static conditions for $96 \mathrm{~h}$. After completion of fermentation, enzymes were extracted from the fermented media as per Alva et al. [11] with slight modifications. Harvested culture of the fermented broth was centrifuged at 10,000 rpm for $30 \mathrm{~min}$ at $4{ }^{\circ} \mathrm{C}$ and the cell free supernatant obtained was used as crude amylase and protease enzyme for further assay.

\subsection{Amylase Assay}

Amylase activity was measured in triplicate following the method of Bernfeld [12]. The reaction mixture containing $0.5 \mathrm{ml}$ of $1 \%$ soluble starch solution prepared in $0.2 \mathrm{M}$ acetate buffer ( $\mathrm{pH} 4.0)$ and $0.5 \mathrm{ml}$ of suitably diluted enzyme solution was incubated at $50^{\circ} \mathrm{C}$ for $10 \mathrm{~min}$. Enzyme and reagent blanks were incubated maintaining the same condition simultaneously. After $10 \mathrm{~min}$ of incubation the reaction was terminated by adding $1.0 \mathrm{ml}$ of 3,5 dinitrosalicylic acid (DNS) solution (1 $\mathrm{g}$ of DNS dissolved in $20 \mathrm{ml}$ of $2 \mathrm{M} \mathrm{NaOH}$, to which $30 \mathrm{~g}$ of sodium potassium tartarate and water were added to make it $100 \mathrm{ml}$ ). The reaction mixture was boiled for $15 \mathrm{~min}$ and after cooling O.D. was taken in spectrophotometer at $540 \mathrm{~nm}$. One unit of enzyme activity was defined as the amount of enzyme release $1 \mu \mathrm{mol}$ of reducing sugar per min.

\subsection{Protease Assay}

Extracellular protease activity was determined in triplicate according to the method of van den Hombergh et al. [13]. Each $450 \mu 1$ sample was incubated with $50 \mu 11 \%(w / v)$ BSA (Fraction V, Sigma) in $0.1 \mathrm{M}$ sodium acetate buffer ( $\mathrm{pH} 4.0$ ) at $37^{\circ} \mathrm{C}$. After $30 \mathrm{~min}$ of incubation, the reaction was terminated with $500 \mu \mathrm{l}$ of $10 \%(\mathrm{w} / \mathrm{v})$ trichloroacetic acid (TCA). After incubation at $0^{\circ} \mathrm{C}$ for $30 \mathrm{~min}$, the precipitated proteins were removed by centrifugation at $6000 \mathrm{rpm}$ for 5 min, and the absorbance of the TCA-soluble fraction was estimated as per Lowry et al. [14]. One unit (U) of protease activity was defined as the amount of enzyme that releases 1 $\mu \mathrm{g}$ of tyrosine per min.

\subsection{Separation and Measurement of Dry Cell Biomass}

The biomass content was determined by measuring the dry weight of the fungal sample. The sample was centrifuged at $10,000 \mathrm{rpm}$, at $4^{\circ} \mathrm{C}$ for $10 \mathrm{~min}$ and the fungal biomass was rinsed with sterilized double distilled water and filtered out using Whatman No.1 filter paper. The biomass obtained was dried overnight inside the hot air oven at $80^{\circ} \mathrm{C}$ till the constant weight was attained. Finally, the dry weight of the fungal mycelia was weighed and calculated.

Weight of biomass = weight of dry filter paper with fungal biomass - weight of blank and dry filter paper

[Dry weight of biomass $=$ dry weight of fungus]

\subsection{Immobilization of P. Purpurogenum}

The alginate entrapment of cells was performed according method of Sharma and Satyanarayana [15]. Sodium alginate solution $(3 \%)$ was prepared by dissolving sodium alginate in $100 \mathrm{ml}$ boiling water and autoclaved at $121^{\circ} \mathrm{C}$ for 15 minutes. Both alginate slurry and cell suspension were mixed well i.e. in a ratio of $1: 1$ for 10 minutes to get a uniform mixture. The slurry was taken into a sterile syringe and added drop wise into chilled $0.2 \mathrm{M} \mathrm{CaCl}_{2}$ solution from 5 -cm height and kept for curing at $4^{\circ} \mathrm{C}$ for $1 \mathrm{~h}$. The cured beads were washed with sterile distilled water 3 to 4 times. When the beads were not being used, they were preserved in $0.9 \%$ sodium chloride solution in the refrigerator. All operations were carried out aseptically under laminar flow unit.

Conidia immobilized in beads of calcium alginate were inoculated in fermentation medium and incubated at $30^{\circ} \mathrm{C}$ for $96 \mathrm{~h}$. After successful fermentation, the beads were drained and rinsed with sterile saline solution $(0.8 \% \mathrm{NaCl})$ equal to twice the volume of culture liquor. The beads were then again ready for use in the production of amylase and protease.

\subsection{Production of Amylase and Protease by Repeated Batch Process}

The reusability of immobilized $P$. purpurogenum cells in alginate was examined. Immobilized cells were aseptically inoculated to sterilized fermentation broth of the above agro waste and incubated at $30^{\circ} \mathrm{C}$ for $96 \mathrm{~h}$. Finally, the fermented media were filtered on Whatman No. 1 paper and beads were washed twice with sterile saline solution $(0.8 \% \mathrm{NaCl})$ and kept in phosphate buffer (1 M, pH 7.0). Then, the beads were again introduced into the fresh medium. After attaining maximum enzyme production, the spent medium was replaced with fresh production medium $(50 \mathrm{ml})$ and the process was repeated for five batches until the beads/blocks 
started disintegrating. The enzyme titers and cell leakage of each cycle were determined. Amylase activity was measured following the method described by Bernfeld [12] and extracellular protease activity was determined according to the method of van den Hombergh et al. [13].

\subsection{Statistical Analysis}

Statistical analysis was performed by SPSS, version 10 for windows (SPSS Inc., Chicago, IL, USA).

\section{Results}

\subsection{Liquid Static Surface Fermentation for Production of Amylase and Protease}

In the present study, among the various substrates tested for amylase activity, wheat bran was found to be the best substrate for maximum $(112.64 \mathrm{U} / \mathrm{ml})$ amylase production (Fig. 1). Similarly, in case of production of protease soya powder $(121.23 \mathrm{U} / \mathrm{ml})$ was found to be the best substrate for P. purpurogenum (Fig. 1). Milk powder has also a high potential as a substrate because both protease and amylase activities were found to be very high when used as a substrate.

\subsection{Measurement of Dry Cell Biomass}

Biomass production was found to be different for different substrates. Maximum biomass was obtained from $P$. purpurogenum when cultivated with rice $(4.4 \pm 0.2 \mathrm{~g} / 50 \mathrm{ml})$ at $30^{\circ} \mathrm{C}$ for $96 \mathrm{~h}$ (Fig. 2).

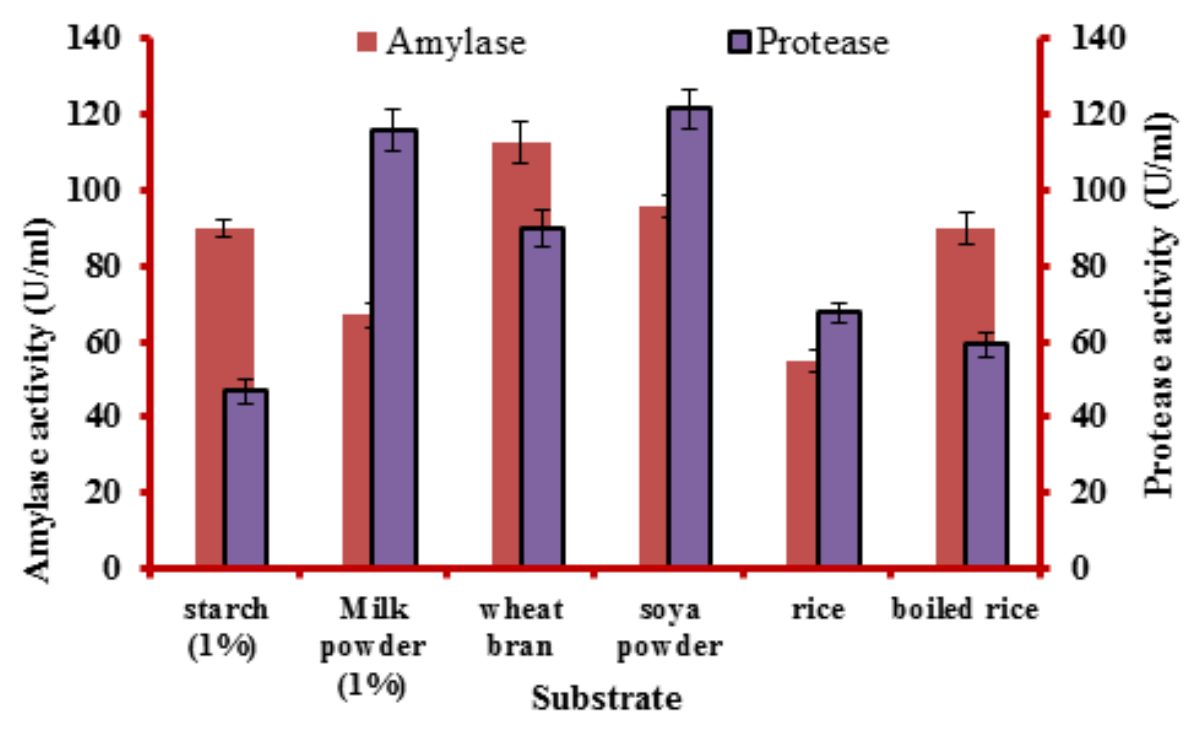

Figure 1. Comparative analysis of amylase and protease production using LSSF by P. purpurogenum

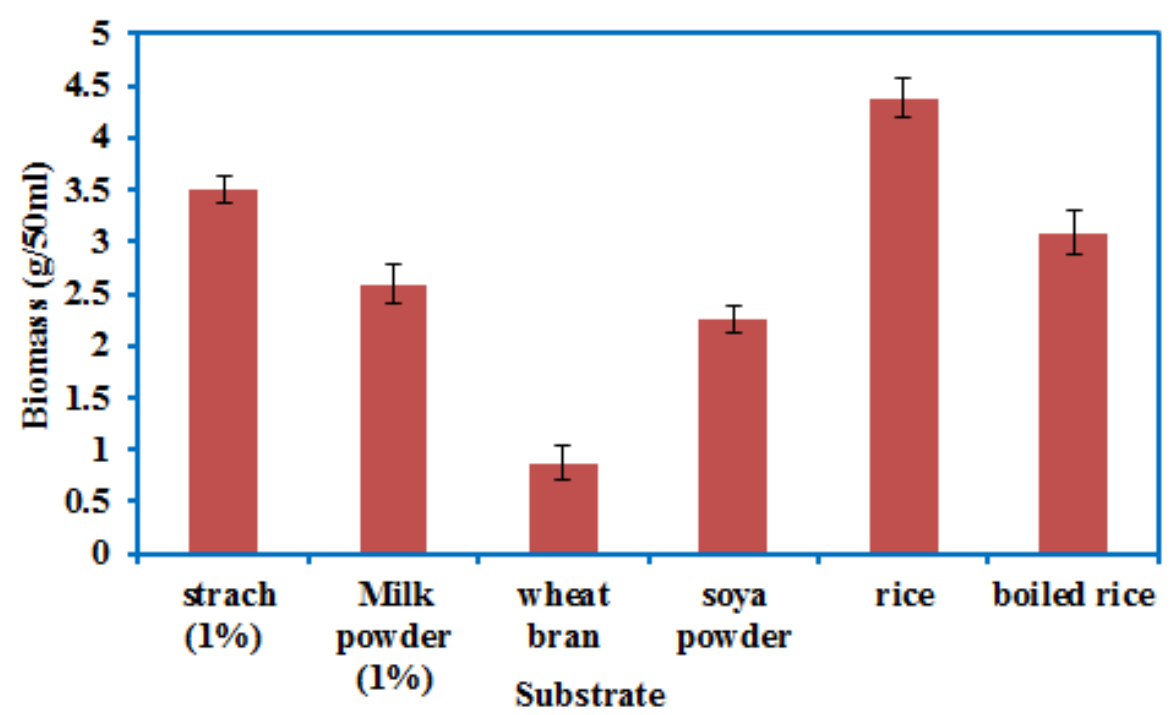

Figure 2. Biomass produced by $P$. purpurogenum under liquid static surface fermentation 


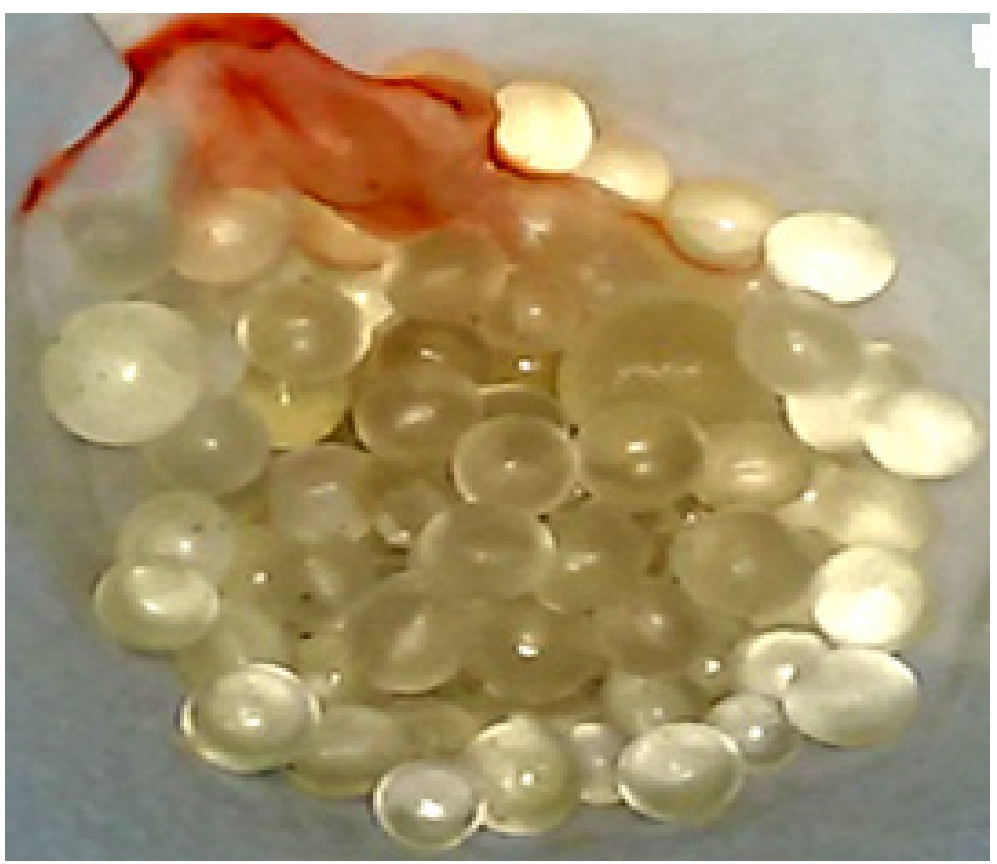

Figure 3. Calcium alginate immobilized spores of $P$. purpurogenum

Table 1. Production of amylase \& protease $(\mathrm{U} / \mathrm{ml})$ using immobilized beads of P. purpurogenum

\begin{tabular}{|c|c|c|c|c|c|c|c|c|}
\hline \multirow{2}{*}{$\begin{array}{c}\text { Batch } \\
\text { operation }\end{array}$} & \multicolumn{2}{|c|}{ Unboiled rice } & \multicolumn{2}{c|}{ Boiled rice } & \multicolumn{2}{c|}{ Wheat bran } & \multicolumn{2}{c|}{ Soya powder } \\
\cline { 2 - 9 } & Amylase & Protease & Amylase & Protease & Amylase & Protease & Amylase & Protease \\
\hline First & 68.84 & 73.51 & 91.56 & 63.61 & 119.92 & 89.91 & 97.91 & 121.95 \\
\hline Second & 78.91 & 80.90 & 97.04 & 69.60 & 137.6 & 101.32 & 109.32 & 130.73 \\
\hline Third & 56.86 & 64.93 & 93.9 & 63.73 & 115.94 & 94.85 & 100.25 & 119.91 \\
\hline
\end{tabular}

\subsection{Immobilization of P. Purpurogemum Spores for Production of Amylase and Protease}

The reusability of alginate immobilized spores for amylase and protease production was studied. Beads entrapping $P$. purpurogenum spores (Fig.3) were successfully used in 3 repeated cycles of fermentation using unboiled rice, boiled rice, wheat bran and soya seed powder as the substrates. The production of amylase and protease gradually increase from first cycle to the second cycle and decrease thereafter. Maximum production of amylase (137.6 $\mathrm{U} / \mathrm{ml}$ ) was attained with wheat bran whereas the production of protease $(130.73 \mathrm{U} / \mathrm{ml})$ with soya powder (Table 1).

\section{Discussion}

Bacterial amylases and proteases have long been used in industry, but, now-a-days, they are replaced by fungal amylases as these enzymes can be effortlessly extracted and separated from fungal biomass [16]. Liquid static and/or solid state fermentation can be used for the large-scale production of these enzymes. Numerous amylase-producing organisms have been documented [17, 18]. For example, many species of genus Aspergillus are renowned for their ability to degrade starch. Khan and Yadav [19] have isolated four fungi from soil and were screened for alpha amylase production. Among these four fungi, Aspergillus niger was found to have best activity among all the four isolates.

In the present study, various agro-substrates were screened for both amylase and protease production by LSSF. Among the various substrates tested for amylase activity, wheat bran was found to be the best substrate for amylase production by $P$. purpurogenum. In the present study, due to significantly higher volumetric activity achieved with wheat bran, it was used in the modified fermentation medium. It is important to note that this substrate is economic and could be employed for industrial production of amylase. Biosynthesis of manifold forms of glucoamylase (GA) and production of acid protease with wheat bran as a substrate by different fungal sp. were also reported earlier [20, 21, 22]. Sindhu et al. [23] have studied the effect of incubation period on the production of protease using $P$. godlewskii SBSS 25 and reported the highest production of enzyme on the fourth day of cultivation in SmF which is at par with the present finding.

Immobilization technique is generally employed for the entrapment of microbial cells, biocatalysts and other metabolites for the repeated use. But, recently, it has been extended to fungi. Immobilized fungal spore/cells were first applied for the biotransformation of cortex lone to 
hydrocortisone by Curvularia lunata and of glucose to itaconic acid by A. terreus. At present, immobilization of fungi is studied for numerous applications in industrial processes in which only free mycelia were used earlier. Immobilization of fungal spores/cells and their enzymes has become one of the most precious techniques in the field of modern biotechnology [24]. Furthermore, this encapsulation provides prolonged metabolic activity when microbial cells are repeatedly used and it also provides protection to the organism from inhibitory compounds or metabolites. Similarly, El-Katatny et al. [24] have also encapsulated the Trichoderma spp. for enhanced production of cell wall degrading enzyme.

\section{Conclusions}

Developing countries, like, India is rich in agricultural residues and are the most abundant renewable resources which can be used for the production of enzymes and other metabolites by different microorganisms. Production of enzymes from such residues will have an enormous potential as it is environmental-friendly and sustainable alternative to costly substrates. Further, the use of native and potent microorganisms is essential to attain economic production of enzymes. In this context, $A$. terreus and $P$. purpurogenum could be the prospective candidates for both amylase and protease production by LSSF with agro- substrates. In the present biotechnological era, $\alpha$-amylases and proteases are applied in biopharmaceutical applications, though, their major applications in food and detergent industries. Further, use of immobilization techniques in enzyme production will greatly reduce the high capital investment and in alternate, it will reduce the final cost of the product.

\section{REFERENCES}

[1] J.E. Smith. Enzyme technology. In: Biiotechnology 3rd edn. Cambridge University press, UK, pp 68-83, 1996.

[2] H.M. Cherry, M.T. Hossain, M.N. Anwar. Extracellular Glucoamylasefrom the Isolate Aspergillus fumigatus, Pakistan Journal of Biological Science, Vol.7, No.11, 19881992, 2004.

[3] N.M. Sidkey, M.A. Al-Rahman Abo-Shadi, A.M. AlMutrafy, F. Sefergy, N. Al-Reheily. Screening of microorganisms isolated from some environ-Agro-industrial wastes in Saudi Arabia for $\alpha$-amylase production, Journal of American Science, Vol.6, No.10, 926-939, 2010.

[4] F. Rezaei, D. Xing, R. Wagner, J.M. Regan, T.L. Richard, B.E. Logan. Simultaneous cellulose degradation and electricity production by Enterobactereoacae in an MFC, Applied \& Environmental Microbiology, Vol.192, 304-309, 2009.

[5] E.A. Abu, S.A. Ado, D.B. James. Raw starch digesting amylase production by mixed culture of Aspergillus niger and Saccaromyces cerevisae grown on sorghum pomace, African Journal of Biotechnology, Vol.4, No.8, 785-790, 2005.

[6] H. Alkan, Z. Baysal, F. Uyar, M. Dogru. Production of lipase by a newly isolated Bacillus coagulans under solid-state fermentation using melon waste, Applied Biochemistry \& Biotechnology, Vol.136, 183-192, 2007.

[7] N. Aro, T. Pakula, M. Penttila. Transcriptional regulation of plant cell wall degradation by filamentous fungi, FEMS Microbiology Review, Vol. 29, 719-739, 2005.

[8] P.G. Cardoso, J.B. Ribeiro, J.A. Teixeira, M.V. Queiroz, E.F. Arau'jo. Over-expression of the plgl gene encoding pectin lyase in Penicillium griseoroseum, Journal of Industrial Microbiology \& Biotechnology, 35, 159-166, 2007.

[9] R.C. Dubey, D.K. Maheswari. A Textbook of Microbiology. S. Chand and Co. Ltd. ISBN: 81-219-2153-8, 2007.

[10] B.K. Sethi, J.R. Rout, R. Das, P.K. Nanda, S.L. Sahoo. Lipase production by Aspergillus terreus using mustard seed oil cake as a carbon source, Annals of Microbiology, Vol. 63, 241252, 2013.

[11] S. Alva, J. Anupama, J. Salva, Y.Y. Chiu, P. Vyashali, M. Shruti, B.S. Yogeetha, D. Bhavya, J. Purvi, K. Ruchi, B.S. Kumudini, K.N. Varalakshmi. Production and characterization of fungal amylase enzyme isolated from Aspergillus sp. JGI 12 in solid state culture, African Journal of Biotechnology, Vol. 6, No. 5, 576-581, 2007.

[12] P. Bernfeld. Amylase $\alpha$ and $\beta$, In Methods in Enzymology (Colowick SP, Kaplan NO, ed.), Academic Press Inc, New York, vol.1, pp.149-158, 1955.

[13] J.P.T.W. van den Hombergh, P.J.I. van de Vondevoort, N.C.B.A. van der Heijden, J. Visser, New protease mutants in Aspergillus niger result in strongly reduced in vitro degradation of target proteins: genetic and biochemical characterization of seven complementation groups., Curr. Genet., 28299-28308, 1995.

[14] O.H. Lowry, N.J. Rosebrough, A.L. Farr, R.J. Randall. Protein measurements with the folin phenol reagent, Journal of Biological Chemistry, Vol.193, 265-275, 1951.

[15] A. Sharma, T. Satyanarayana. Production of acid-stable and high-maltose-forming $\alpha$-amylase of Bacillus acidicola by solid-state fermentation and immobilized cells and its applicability in baking, Applied Biochemistry \& Biotechnology, Vol. 168, 1025-1034, 2012.

[16] S.U. Phadatare, V.V. Deshpande, M.C. Srinivasa. High activity alkaline protease from Conidiobolus coronatus $(\mathrm{NcL}$ 86. 8.20). Enzyme production and compatibility with commercial detergents, Enzyme \& Microbial Technology, Vol.15, 72-76, 1993.

[17] K. Kathiresan, S. Manivannan. $\alpha$-amylase production by Penicillium fellutanum isolated from mangrove rhizosphere soil, African Journal of Biotechnology, Vol. 5, 829-832, 2006.

[18] J.A. Grillo, A.K. Lawal. In vitro activity of Thaumatococcus danielli and Megaphrynium macrostachyum against spoilage fungi of white bread and 'Eba' an indigenous staple food in southern Nigeria, African Journal of Microbiological Research, Vol.4, No.11, 1076-1081, 2010. 
[19] J.H. Khan, S.K. Yadav. Production of alpha amylases by Aspergillus niger using cheaper substrates employing solid state fermentation, International Journal of Plant, Animal \& Environmental Science, Vol.1, No. 3, 45-51, 2011.

[20] T. Aalbæk, R. Morten, B. Jensen, H. Susanne, K. Eriksen. Acid protease and formation of multiple forms of amylase in batch and continuous cultures of Aspergillus niger, Enzyme \& Microbial Technology, Vol. 30, 410-415, 2002.

[21] S. Negi, R. Banerjee. Characterization of amylase and protease produced by Aspergillus awamori in single bioreactor, Food Research. International, Vol. 42, 443-448, 2009.
[22] S. Negi, R. Banerjee. Optimization of culture parameters to enhance production of amylase and protease from Aspergillus awamori in a single fermentation., African Journal of Biochemistry Research, Vol. 4, No. 3, 73-80, 2010.

[23] R. Sindhu, G.N. Suprabha, S. Shashidhar. Optimization of process parameters for the production of alkaline protease from Penicillium godlewskii SBSS 25 and its application in detergent industry, African Journal of Microbiological Research, Vol.3, No.9, 515-522, 2009.

[24] M.H. El-Katatny, A.H. Hetta, G.M. Shaban, H.M. El-Komy. Enzyme Production by Alginate Encapsulated Trichoderma spp., Food Technology \& Biotechnology, Vol. 41, No. 3, 219-225, 2003. 